\title{
Influence of Trans-Boundary Air Pollution on the Urban Atmosphere in Fukuoka, Japan
}

\author{
Ayako Yoshino ${ }^{1}$, Akinori Takami ${ }^{1, *}$, Kei Sato ${ }^{1}$, Atsushi Shimizu ${ }^{1}$, Naoki Kaneyasu ${ }^{2}$, \\ Shiro Hatakeyama ${ }^{3}$, Keiichiro Hara ${ }^{4}$ and Masahiko Hayashi ${ }^{4}$ \\ 1 Center for Regional Environmental Research, National Institute for Environmental Studies, \\ Ibaraki 305-8506, Japan; yoshino.ayako@nies.go.jp (A.Y.); kei@nies.go.jp (K.S.); shimizua@nies.go.jp (A.S.) \\ 2 National Institute of Advanced Industrial Science and Technology, Ibaraki 305-8569, Japan; kane.n@aist.go.jp \\ 3 Institute of Agriculture, Tokyo University of Agriculture and Technology, Tokyo 183-8509, Japan; \\ hatashir@cc.tuat.ac.jp \\ 4 Department of Earth System Sciences, Fukuoka University, Fukuoka 814-0180, Japan; \\ harakei@fukuoka-u.ac.jp (K.H.); mhayashi@fukuoka-u.ac.jp (M.H.) \\ * Correspondence: takamia@nies.go.jp; Tel.: +81-29-850-2509; Fax: +81-29-850-2579
}

Academic Editor: Shinji Wakamatsu

Received: 9 February 2016; Accepted: 24 March 2016; Published: 30 March 2016

\begin{abstract}
To understand the influence of trans-boundary air pollution on the air quality of Fukuoka, the mass concentration and chemical composition of fine particulate matter (PM) were observed at urban (Fukuoka) and rural (Fukue Island) sites in the northern Kyushu area in Japan. Chemical composition was measured using an aerosol mass spectrometer. Organic aerosol (OA) data were analyzed by the positive matrix factorization (PMF) method. Sulfate and low-volatile oxygenated OA (LV-OOA) were dominant for all of the $\mathrm{PM}_{2.5}$ mass variations on Fukue Island, where the trans-boundary air pollution is dominant in the winter-spring season. In Fukuoka, however, sulfate accounted for the largest fraction of total chemical species under high $\mathrm{PM}_{2.5} \mathrm{mass}$ concentrations $\left(>35 \mu \mathrm{g} \cdot \mathrm{m}^{-3}\right.$ ), while organics and nitrate made up a large fraction under low $\mathrm{PM}_{2.5}$ $\left(<10 \mu \mathrm{g} \cdot \mathrm{m}^{-3}\right)$. Under the high $\mathrm{PM}_{2.5}$ condition, LV-OOA was also dominant. This indicates that high $\mathrm{PM}_{2.5}$ mass concentrations were attributed to the long-range transport of air pollution. Although the trans-boundary air pollution prevails in the winter-spring season, high sulfate concentrations were observed in the summer of 2012. In addition to the volcanic activities and photochemical reactions, long-range, trans-boundary air pollutions are influential factors not only in winter-spring but also in summer.
\end{abstract}

Keywords: aerosol mass spectrometer; particulate matter; organic aerosol; positive matrix factorization; long-range transport

\section{Introduction}

Air pollution emissions from East Asia have increased in recent years in connection to rapid economic growth. Kurokawa et al. [1] reported that emission of air pollutants in East Asia significantly increased from 2000 to 2008 . These air pollutants mainly consist of sulfur dioxide $\left(\mathrm{SO}_{2}\right)$, nitrogen oxides $\left(\mathrm{NO}_{x}\right)$, carbon monoxide (CO), volatile organic compounds (VOCs), and their emissions in 2008 (growth rate between from 2000 to 2008$)$ were increasing $56.9 \mathrm{Tg}(+34 \%), 53.9 \mathrm{Tg}(+54 \%), 359.5 \mathrm{Tg}(+34 \%)$, and $68.5 \mathrm{Tg}(+46 \%)$, respectively. China contributed to the Asian emissions for largest fraction in Asian countries because of continuous increase in its energy consumption, and their emissions of each species are $33.5 \mathrm{Tg}(+46 \%), 27.0 \mathrm{Tg}(89 \%), 202.0 \mathrm{Tg}(+42 \%)$, and $27.1 \mathrm{Tg}(+71 \%)$, respectively [1]. It is reported that $\mathrm{SO}_{2}$ emissions in China decreased after 2006 [2]; however, emissions of these air pollutants in China still increased monotonically [1]. It is well known that these air pollutants are transported 
throughout the continent from China to Japan with seasonal monsoons in winter and spring [3-9]. Many recent studies reported that atmospheric aerosol was transported from mainland China to the northern part of the Kyushu area and Okinawa, which face the East China Sea in Japan [3-9]. In these studies, high concentrations of particulate matter $\left(\mathrm{PM}_{2.5}\right)$, which were noted to be over environmental quality standards in Japan for $24 \mathrm{~h}$ of $35 \mu \mathrm{g} \cdot \mathrm{m}^{-3}$, were observed. We observed chemical composition of atmospheric aerosol by using an aerosol mass spectrometer and a filter sampling method at Cape Hedo in Okinawa, and on Fukue Island, Nagasaki, in Japan in previous studies. Both sites are located on the windward side of the seasonal monsoons in winter and spring. High concentrations of sulfate were observed when the air mass was transported from mainland China to these sites [3,4,8-12].These high values were considered to be due to trans-boundary air pollution [3,4,8-12]. It is, therefore, important to understand the transport of air pollutants including PM.

Fukuoka, one of the largest cities in Japan, is located in the northern part of the Kyushu area in the western part of Japan. The population of Fukuoka is about 1.5 million and there are numerous commercial, residential, and industrial areas. Therefore, local emission in Fukuoka is expected to be high. Since Fukuoka is influenced by both local emissions and long-range transported air pollution, the city's exposure to air pollution is expected to be high [9]. In order to improve Fukuoka's air quality, it is necessary to assess the contributions from both local and transported air pollutants.

PM mass concentrations and chemical composition were observed on Fukue Island, which is in a rural area located in the East China Sea, approximately $180 \mathrm{~km}$ west of Fukuoka. Although Fukue Island is mostly influenced by transported air pollutants, a similar level of $\mathrm{PM}_{2.5}$ mass concentrations were observed in both Fukuoka and Fukue Island, despite a large difference in local emissions [6,7]. This indicates that air pollution transported from mainland China, spreads over a very wide area, which includes both Fukuoka and Fukue Island.

PM mass concentration and chemical composition were measured both in Fukuoka and on Fukue Island in order to assess the contributions from both local and transported air pollutants. The chemical composition of PM reflects their transport process [9]. Thus, we measured PM mass and chemical composition and classified the chemical composition with respect to $\mathrm{PM}_{2.5}$ mass concentration. A positive matrix factorization (PMF) method was applied to analyze the organic composition, which is also considered to reflect their transport process.

\section{Experiments}

\subsection{Locations and Periods}

The chemical composition and mass concentration of atmospheric fine aerosol, i.e., particulate matter (PM), were observed in two sites in 2012 (Figure 1). The first was an urban site: Fukuoka, Fukuoka prefecture $\left(33.55^{\circ} \mathrm{N}, 130.36^{\circ} \mathrm{E}\right)$. The observation was carried out at the Fukuoka University, which is located $5 \mathrm{~km}$ away from the downtown area and the city highway is about several hundred meters away. Fukuoka is one of the largest cities in Japan with a population around 1.5 million. There is a large network of transportation infrastructure including railways, highways, and the airport $[6,7,9]$. The second observation site was rural: Fukue Island, Nagasaki prefecture $\left(32.75^{\circ} \mathrm{N}\right.$, $128.68^{\circ} \mathrm{E}$ ). The population is approximately 40,000 and it is generally considered to have few emission sources [3,5-7]. Observations were conducted throughout 2012, with the exception of summer (from June to September) on Fukue Island. 


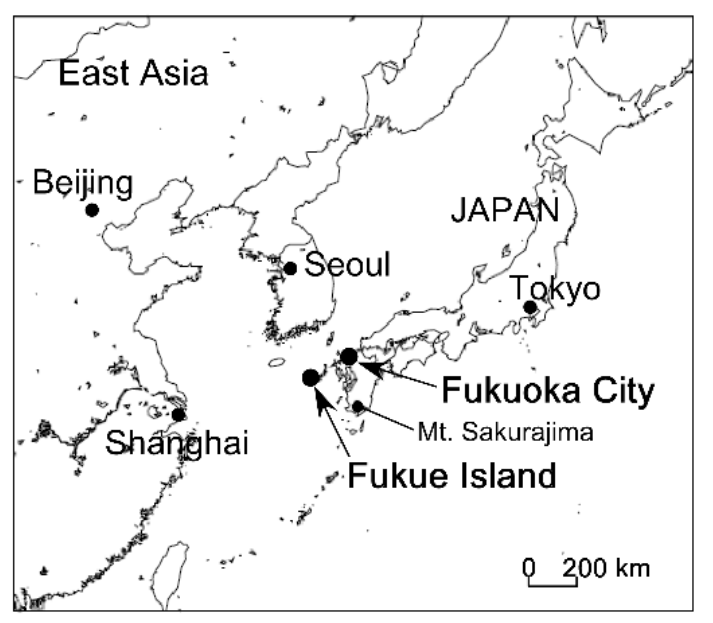

Figure 1. Location of Fukuoka City and Fukue Island in East Asia.

\subsection{Instruments}

The chemical composition of fine aerosol $\left(\mathrm{PM}_{1}\right)$ in Fukuoka City was observed by using a quadrupole-type aerosol mass spectrometer (Q-AMS, Aerodyne Research Inc., Billerica, MA, USA. An aerosol inlet with PM $_{2.5}$ cut cyclone (URG-2000-30ED, URG Co., Chapel Hill, NC, USA) was set on a window of the fourth floor of the Faculty of Science Building (about $20 \mathrm{~m}$ from the ground) at Fukuoka University. The cyclone removed coarse particles. Sample air was introduced through an o.d. $3.18 \mathrm{~mm}$ stainless steel tube (main sampling line with o.d. $12.7 \mathrm{~mm}$ connected to the inlet tube for the implementation of isokinetic sampling), $0.1 \mathrm{~mm}$ pore size orifice, and an aerodynamic lens into the Q-AMS with the flow rate at $0.1 \mathrm{~L} \cdot \mathrm{min}^{-1}$. The sample air was separated into gases and aerosols by the aerodynamic lens and particle beam formed. The particle beam hit the vaporizer, with a temperature set to $873 \mathrm{~K}\left(600{ }^{\circ} \mathrm{C}\right)$, and where non-refractory species in the aerosol were vaporized. The vaporized molecules were ionized by the electron impact method with $70 \mathrm{eV}$. The ions were analyzed using a quadrupole type mass spectrometer. The particle mass was calibrated using ammonium nitrate $\left(\mathrm{NH}_{4} \mathrm{NO}_{3}\right)$ particles with a $350 \mathrm{~nm}$ diameter, and the ionization efficiency (IE) and the relative ionization efficiency (RIE) were determined. The averaged IE for $\mathrm{NO}_{3}{ }^{-}$was $7.50 \times 10^{-7}$, RIE for $\mathrm{NH}_{4}{ }^{+}$was 3.36. The collection efficiency (CE) for all the measured species was 1.0. Sulfate, nitrate, ammonium, and chloride were calculated from the fragment signals of the mass spectra. Organics were calculated by subtracting the known inorganic and gaseous species, such as sulfate, nitrate, nitrogen, oxygen, and argon from the total mass. The details of the Q-AMS and calibration procedures are described in the literature [3,4,13-17]. For measuring $\mathrm{PM}_{2.5}$ mass concentrations, an air pollution monitoring station using beta-ray absorption technique was set up at Kashii which belongs to municipal government offices of Fukuoka City.

On Fukue Island, aerosol chemical composition was measured using a quadrupole-type aerosol chemical speciation monitor (Q-ACSM, Aerodyne Research Inc., Billerica, MA, USA). The Q-ACSM is a simplified version of Q-AMS, and the principle of the measurement is also the same. The averaged IE for $\mathrm{NO}_{3}{ }^{-}$was $2.82 \times 10^{-11}$, RIE for $\mathrm{NH}_{4}{ }^{+}$was 6.03. The $\mathrm{CE}$ for all the measured species was 0.5 . The sampling inlet with cyclone was set to the rooftop of the building at the Observatory of Atmospheric Environment on Fukue Island (about $3 \mathrm{~m}$ from the ground). Mass concentrations of $\mathrm{PM}_{2.5}$ were measured using a tapered element oscillating microbalance (TEOM, Model 1400a, R\&P Co. Inc., East Greenbush, NY, USA).

\subsection{Analysis}

Organic data obtained by Q-AMS and Q-ACSM were analyzed by the PMF method, originally invented by Paatero [18,19]. The analysis was carried out using the PMF evaluation tool for the aerosol 
mass spectrometer developed by Ulbrich et al. [20]. PMF is a receptor-only factorization method. PMF method processes multiple environmental data and calculates factor profiles and contributions. All of the values in the profiles and contributions are constrained to be positive. Since we measured the aerosol chemical composition only in the receptor area (Fukuoka City and Fukue Island), we adopted the PMF method to analyze our Q-AMS and Q-ACSM organic data. The factor profiles and contributions can provide sources of organic aerosol measured by Q-AMS and Q-ACSM.

Backward trajectories were calculated using the National Oceanic and Atmospheric Administration (NOAA) Hybrid Single Particle Lagrangian Integrated Trajectory Model (HYSPLIT) [21,22] to track the pathway of air mass (NOAA Air Resouces Laboratory, College Park, MD, USA). Starting altitude and calculation time were set to be $500 \mathrm{~m}$ and $48 \mathrm{~h}$, respectively. The spatial distribution of sulfate was also investigated using Chemical Weather Forecasting System (CFORS) numerical simulations [23,24].

\section{Results}

\subsection{Chemical Composition}

Figure $2 \mathrm{a}, \mathrm{b}$ shows variations in the PM mass concentrations and chemical composition measured in Fukuoka City and Fukue Island. Monthly averages of each of these values is listed in Table 1. For Fukuoka, there are several periods when data were missing due to the Q-AMS pump trouble. Because the main focus was on trans-boundary air pollution from mainland China, data for Fukue Island were measured only from January to May and then from October to December to correspond to the pollution's winter-spring season. Total mass concentrations of chemical components (stack on graph) show a similar variation with that of $\mathrm{PM}_{2.5}$ mass concentrations. While sulfate and organics are major components in both sites, nitrate is more significant in Fukuoka City than that on Fukue Island. High $\mathrm{PM}_{2.5}$ and sulfate events were observed several times in both sites in spring and summer.
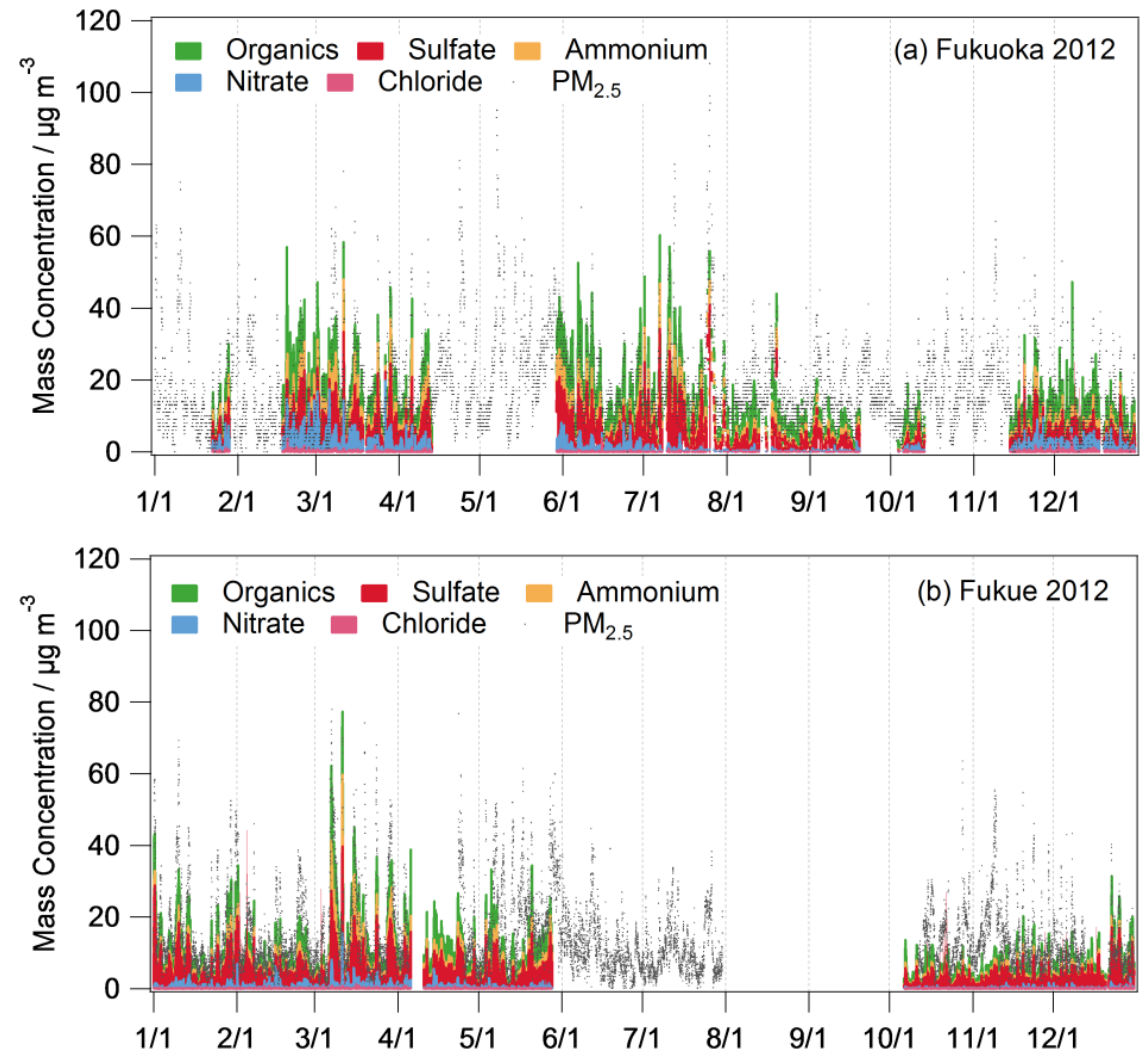

Figure 2. Variations of mass concentrations of $\mathrm{PM}_{2.5}$ (dot) and chemical composition of $\mathrm{PM}_{1}$ during 2012. (a) Fukuoka City (b) Fukue Island. 
Table 1. Monthly averaged mass concentrations of $\mathrm{PM}_{2.5}$ and chemical composition in Fukuoka City and on Fukue Island in 2012.

\begin{tabular}{|c|c|c|c|c|c|c|}
\hline \multicolumn{7}{|c|}{ Fukuoka City/ $\mu \mathrm{g} \cdot \mathrm{m}^{-3}$} \\
\hline Month & $\mathbf{P M}_{2.5}$ & Ammonium & Nitrate & Sulfate & Chloride & Organics \\
\hline January & 16 & 1.3 & 1.0 & 2.5 & 0.1 & 2.7 \\
\hline February & 13 & 3.1 & 2.5 & 4.9 & 0.3 & 6.4 \\
\hline March & 19 & 2.7 & 1.7 & 4.4 & 0.1 & 4.6 \\
\hline April & 20 & 2.1 & 0.8 & 3.8 & 0.1 & 3.7 \\
\hline May & 26 & - & - & - & - & - \\
\hline June & 18 & 2.1 & 0.8 & 4.5 & 0.1 & 6.2 \\
\hline July & 23 & 2.6 & 0.4 & 7.2 & 0.0 & 4.8 \\
\hline August & 15 & 0.8 & 0.2 & 2.2 & 0.0 & 3.3 \\
\hline September & 16 & 1.1 & 0.2 & 2.5 & 0.0 & 2.3 \\
\hline October & 15 & 0.9 & 0.4 & 1.6 & 0.0 & 2.7 \\
\hline November & 16 & 1.5 & 1.0 & 2.7 & 0.1 & 3.4 \\
\hline December & 11 & 1.4 & 0.9 & 2.6 & 0.1 & 2.7 \\
\hline \multicolumn{7}{|c|}{ Fukue Island $/ \mu \mathrm{g} \cdot \mathrm{m}^{-3}$} \\
\hline Month & $\mathrm{PM}_{2.5}$ & Ammonium & Nitrate & Sulfate & Chloride & Organics \\
\hline January & 16 & 1.2 & 0.4 & 4.6 & 0.0 & 3.3 \\
\hline February & 13 & 0.9 & 0.3 & 3.6 & 0.0 & 2.5 \\
\hline March & 20 & 2.7 & 0.7 & 5.6 & 0.1 & 4.2 \\
\hline April & 14 & 1.3 & 0.4 & 4.0 & 0.1 & 3.4 \\
\hline May & 20 & 1.3 & 0.2 & 4.1 & 0.0 & 3.5 \\
\hline June & 14 & - & - & - & - & - \\
\hline July & - & - & - & - & - & - \\
\hline August & - & - & - & - & - & - \\
\hline September & - & - & - & - & - & - \\
\hline October & 14 & 0.5 & 0.1 & 1.9 & 0.0 & 1.6 \\
\hline November & 15 & 0.6 & 0.1 & 2.2 & 0.0 & 1.7 \\
\hline December & 11 & 0.6 & 0.1 & 3.5 & 0.0 & 2.0 \\
\hline
\end{tabular}

Figure 3a,b show the breakdown of the chemical composition of PM measured in Fukuoka City and Fukue Island under high $\left(>35 \mu \mathrm{g} \cdot \mathrm{m}^{-3}\right)$, middle $\left(10-35 \mu \mathrm{g} \cdot \mathrm{m}^{-3}\right)$, and low $\left(<10 \mu \mathrm{g} \cdot \mathrm{m}^{-3}\right)$ $\mathrm{PM}_{2.5}$ mass concentrations for 2012. On Fukue Island, sulfate accounted for approximately $50 \%$, which is the largest fraction of total PM, and nitrate was minor in every case. The fraction of each chemical component did not change with $\mathrm{PM}_{2.5}$ mass variation. In contrast, in the case of high $\mathrm{PM}_{2.5}$ concentrations in Fukuoka City during the observation period, sulfate accounted for the largest fraction of total PM measured by Q-AMS for the event of highest $\mathrm{PM}_{2.5}$ concentration, while organics and nitrate made up a large fraction under low $\mathrm{PM}_{2.5}$ concentrations. High levels of sulfate within high $\mathrm{PM}_{2.5}$ concentrations are similar to the results for Fukue Island.

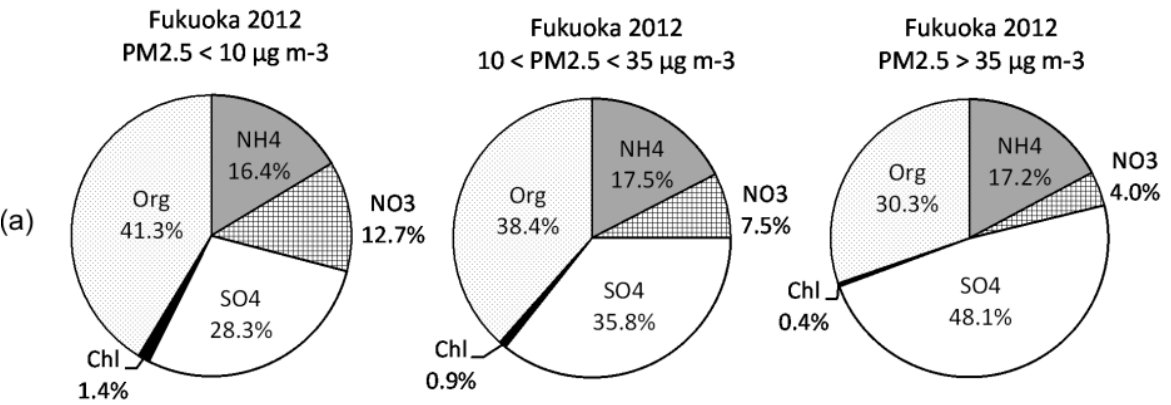

Figure 3. Cont. 

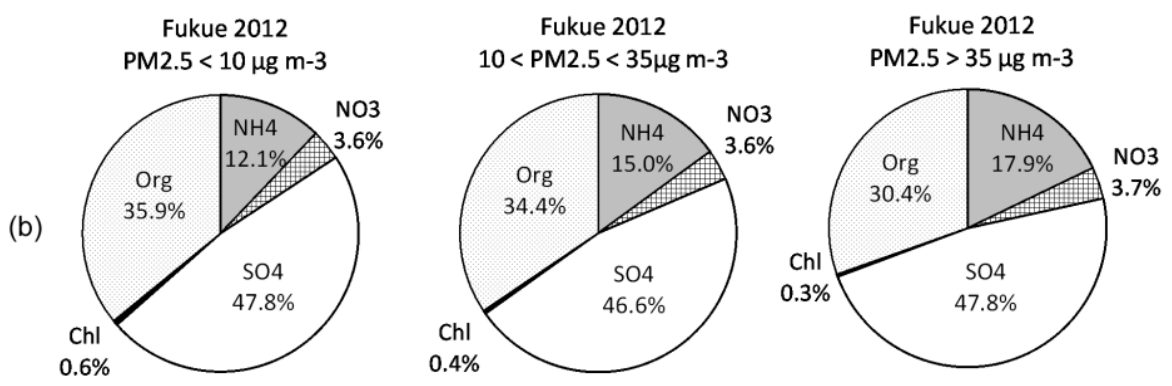

Figure 3. Breakdown of chemical composition of PM measured using Q-AMS. NH4: ammonium, NO3: nitrate, SO4: sulfate, Chl: chloride, Org: organics. (a) Fukuoka City (b) Fukue Island.

\subsection{PMF Analysis}

The organic spectra of Q-AMS and Q-ACSM were analyzed using the PMF method. They were analyzed with two factors given that the focus was only on air pollution from long-range transport or from local emissions. Figures $4 \mathrm{a}$ and $5 \mathrm{a}$ show the mass spectra and variations of mass concentrations of each factor in Fukuoka City. The mass spectra for factor 1 show a distinctive signal of $\mathrm{m} / \mathrm{z}=44$ $\left(\mathrm{COO}^{+}\right.$fragment), this is low-volatile oxygenated organic aerosol (LV-OOA) corresponding to well-aged organics $[17,20,25-27]$. The mass spectra of factor 2 contain $m / z=41,43,55,57$. As for $m / z=43$ (partially aldehydes fragment), they are semi-volatile oxygenated organic aerosols (SV-OOA) corresponding to partially aged organics [17,20,25-27]. As for $m / z=41\left(\mathrm{C}_{3} \mathrm{H}_{5}^{+}\right), 43\left(\mathrm{CH}_{2} \mathrm{CHO}^{+}, \mathrm{C}_{3} \mathrm{H}_{7}^{+}\right)$, $55\left(\mathrm{C}_{4} \mathrm{H}_{7}{ }^{+}\right), 57\left(\mathrm{C}_{4} \mathrm{H}_{9}{ }^{+}\right)$, which are mainly normal alkanes, they are hydrocarbon-like organic aerosols (HOA) corresponding to fresh organics [17,20,25-27]. For the Q-AMS system, $m / z=43$ cannot be separated into aldehyde $\left(\mathrm{CH}_{2} \mathrm{CHO}^{+}\right)$and normal alkane $\left(\mathrm{C}_{3} \mathrm{H}_{7}{ }^{+}\right)$. Thus, two factors are used: one of them is LV-OOA and the other consists of a mixture of SV-OOA and HOA. Figures $4 \mathrm{~b}$ and $5 \mathrm{~b}$ show the result of mass spectra and variation of mass concentrations of each factor on Fukue Island. Similar mass spectra are observed as in Fukuoka City. The signal of $m / z=44$ is large and $m / z=55,57$ are small. For both sites, there were no significant diurnal variations of each factor.
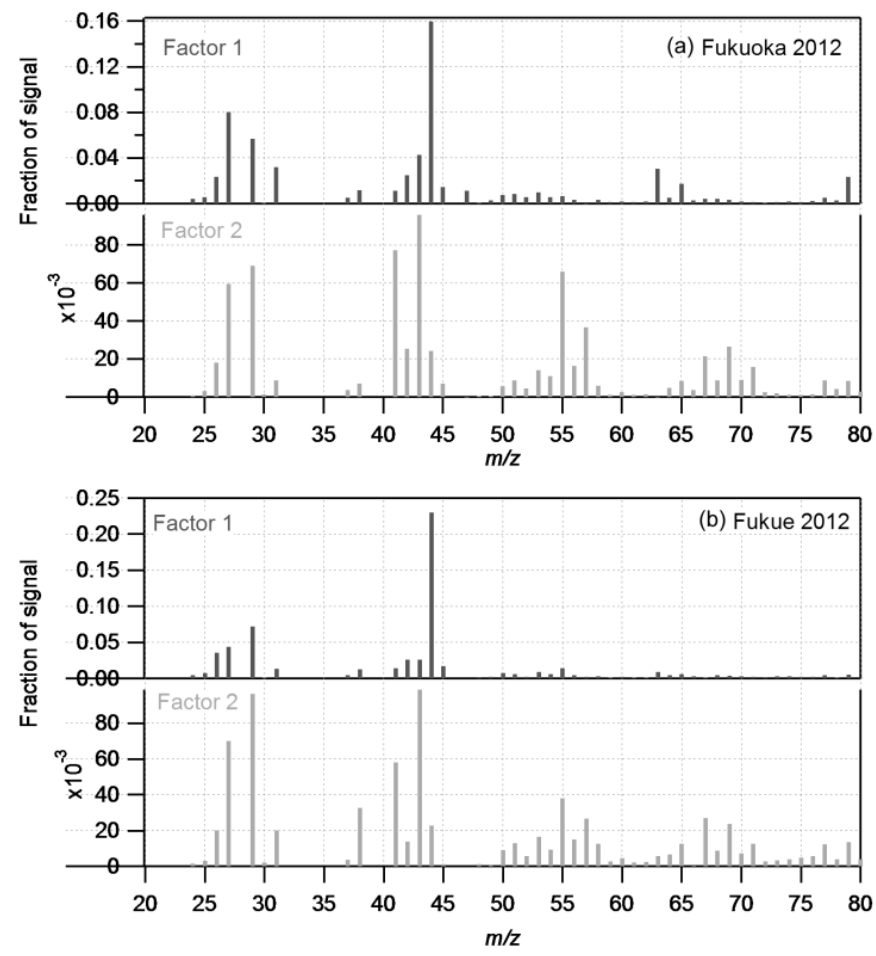

Figure 4. Mass spectra of each factor produced by the PMF analysis. (a) Fukuoka City (b) Fukue Island. 

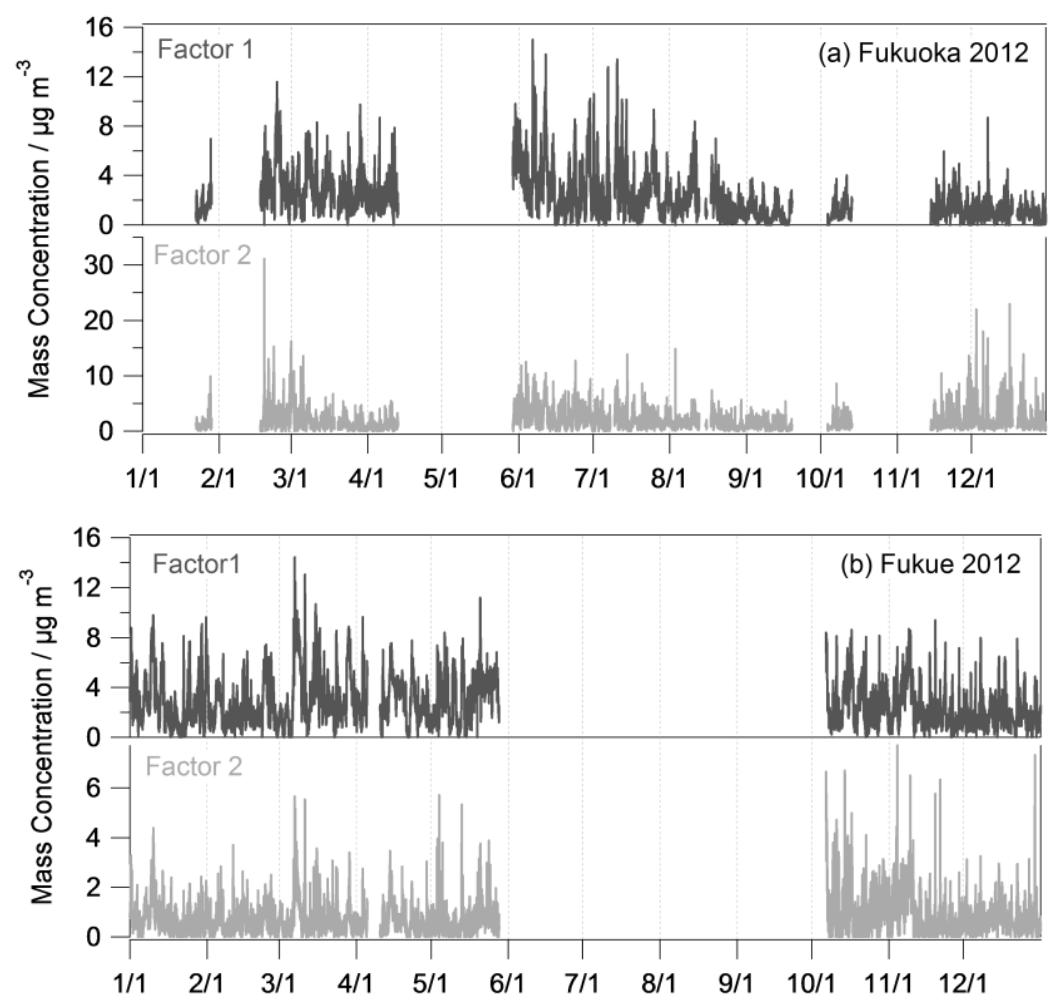

Figure 5. Variations of mass concentration of each factor produced by the PMF analysis. (a) Fukuoka City; (b) Fukue Island.

The fractions of each PMF factor were classified with $\mathrm{PM}_{2.5}$ mass concentrations as in the case with aerosol chemical composition (Figure 6a,b). In Fukuoka City, factor 2 (SV-OOA and HOA) is dominant under low $\mathrm{PM}_{2.5}$ concentrations, where fractions account for approximately $60 \%$ of total mass concentrations. Factor 1 (LV-OOA) made up a large fraction with increasing $\mathrm{PM}_{2.5}$ concentrations. On Fukue Island, factor 1 is dominant under all conditions and the fractions reached approximately $70 \%$.

(a)

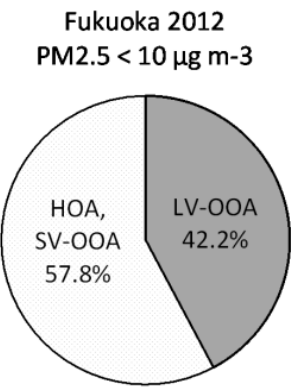

(b)

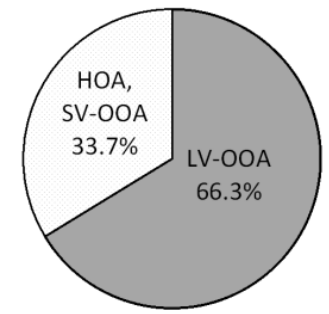

Fukuoka 2012 $10<$ PM2.5 < $35 \mu \mathrm{g} \mathrm{m}-3$

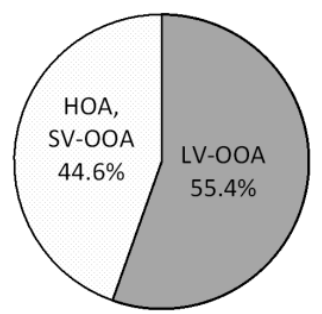

Fukue 2012 $10<$ PM2.5 $<35 \mu \mathrm{g} \mathrm{m}^{-3}$

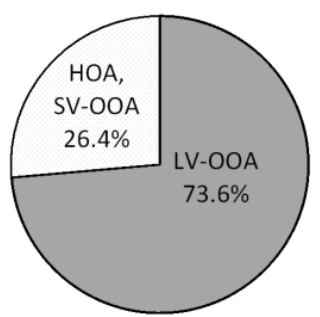

Fukuoka 2012

PM2.5 > $35 \mu \mathrm{g} \mathrm{m}-3$

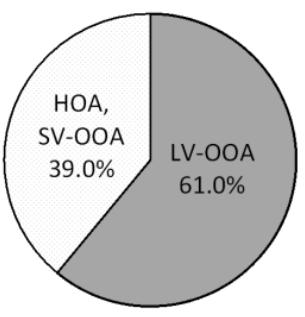

Fukue 2012 PM2.5 > $35 \mu \mathrm{g} \mathrm{m}^{-3}$

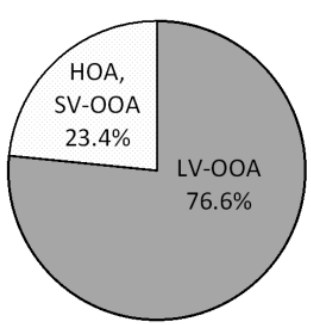

Figure 6. Breakdown of each factor of PMF analysis. (a) Fukuoka City (b) Fukue Island. 


\subsection{Simulation Results}

Figures 7 and 8 show the typical backward trajectories in Fukuoka City and sulfate space distributions in East Asia when sulfate and $\mathrm{PM}_{2.5}$ concentrations are high (7 March) and low (29 February) in spring. In Figure 7a, most of the trajectories end up in mainland China via the East China Sea when $\mathrm{PM}_{2.5}$ mass concentrations are high. In Figure 8a, high sulfate levels cover the region of mainland China all the way to western Japan under high $\mathrm{PM}_{2.5}$ concentrations. These simulations indicate that high sulfate and $\mathrm{PM}_{2.5}$ levels were due to the air pollution transported from mainland China.
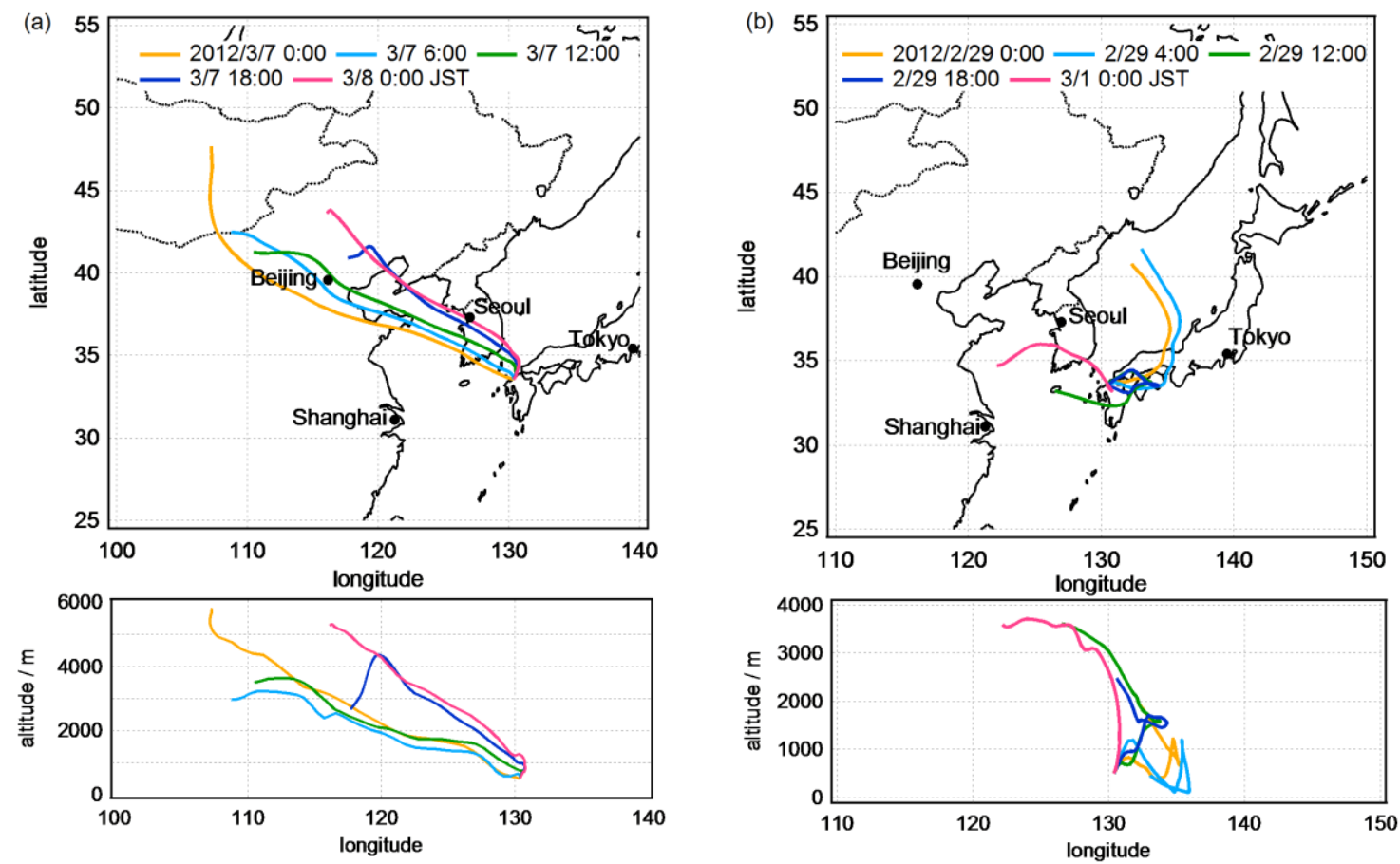

Figure 7. Typical backward trajectory calculations in Fukuoka City. Duration time of the calculations was $48 \mathrm{~h}$. (a) under high $\mathrm{PM}_{2.5}$ concentrations (7 March 2012, daily average of $\mathrm{PM}_{2.5}$ was $41 \mu \mathrm{g} \cdot \mathrm{m}^{-3}$ ); (b) under low $\mathrm{PM}_{2.5}$ concentrations (29 February 2012, daily average of $\mathrm{PM}_{2.5}$ was $6.0 \mu \mathrm{g} \cdot \mathrm{m}^{-3}$ ).

(a) U-V\&Sulf ate $\mathrm{m} / \mathrm{s} \& u g / \mathrm{m}^{3} \quad \mathrm{JST}$ 2012/03/07.00:00:00

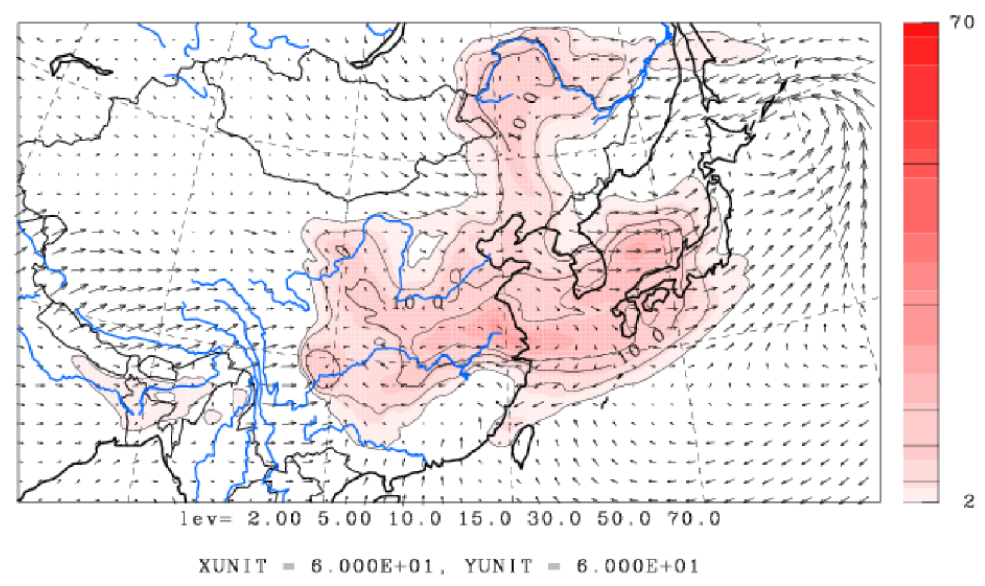

Figure 8. Cont. 
(b) U-V\&Sulf ate $\mathrm{m} / \mathrm{s} \& u g / \mathrm{m} 3$ JST

$2012 / 02 / 29.12: 00: 00$

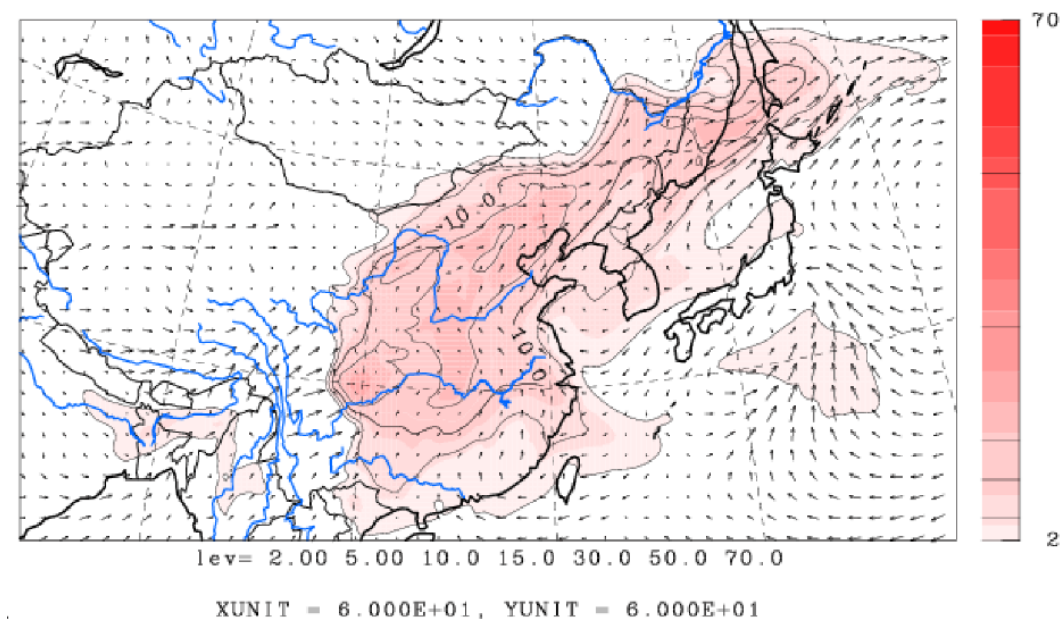

Figure 8. Typical CFORS simulations around East Asia. (a) under high $\mathrm{PM}_{2.5}$ concentrations (7 March 2012); (b) under low $\mathrm{PM}_{2.5}$ concentrations (29 February 2012).

\section{Discussion}

\subsection{Air Quality in Fukuoka City-Local vs. Trans-Boundary Air Pollution}

Fukue Island's population of approximately 40,000 relies heavily on the main industries of fishing and tourism. Therefore, local emissions on Fukue Island are expected to be very low compared to Fukuoka City. Chemical composition shows that sulfate levels are high on Fukue Island, regardless of $\mathrm{PM}_{2.5}$ mass concentrations. The PMF results show that factor 1 (LV-OOA) is dominant. This indicates that the air quality on Fukue Island is mainly influenced by long-range transport of air pollution from mainland China. This is consistent with previous reports [3,5-8].

In Fukuoka City, the results are different from those observed on Fukue Island. The chemical composition varies according to $\mathrm{PM}_{2.5}$ concentrations. High sulfate levels were observed under high $\mathrm{PM}_{2.5}$ concentrations. In this case, factor 1 (LV-OOA) in the PMF analysis is dominant. Under low $\mathrm{PM}_{2.5}$ concentrations, however, nitrate and organic fractions are more prevalent. In addition, factor 2 (SV-OOA and HOA) in the PMF analysis is larger than factor 1 (LV-OOA).

Based on these results, it is considered that the air quality in Fukuoka City is mainly influenced by the long-range transport of air pollution from mainland China when $\mathrm{PM}_{2.5}$ mass concentrations are high $\left(>35 \mu \mathrm{g} \cdot \mathrm{m}^{-3}\right)$. In contrast, when $\mathrm{PM}_{2.5}$ mass concentrations are low $\left(<10 \mu \mathrm{g} \cdot \mathrm{m}^{-3}\right)$, the air quality in the Fukuoka is mainly influenced by local air pollution in and around the Fukuoka. The backward trajectories and the CFORS simulations support these results. As aforementioned, most of the trajectories reach mainland China via the East China Sea, and high sulfate regions cover China to western Japan under high $\mathrm{PM}_{2.5}$ concentrations (Figures 7a and 8a). With low $\mathrm{PM}_{2.5}$ concentrations, the trajectories either reach from the Japanese side or Pacific Ocean, and high sulfate regions are not covering western Japan (Figures $7 \mathrm{~b}$ and $8 \mathrm{~b}$ ). These results are also consistent with the previous report [9].

Air pollution in Fukuoka consists of two parts. The first is local emissions. At low $\mathrm{PM}_{2.5}$ concentrations, the fractions of nitrate and fresh organics (HOA) are relatively large, indicating that combustion is a major contributor to emissions affecting local air quality $[17,25-27]$. The source of this combustion could be any of the several highways, the Fukuoka airport, the Fukuoka shipyard, and numerous commercial areas in Fukuoka City. Therefore, it can be concluded that local emissions influence the local air quality. The other part is air pollution from China. Sulfur dioxide $\left(\mathrm{SO}_{2}\right)$ and nitrogen oxides $\left(\mathrm{NO}_{x}\right)$ in China are still a large component of emissions [1,2,28]. In 2008, $\mathrm{SO}_{2}$ emissions for China and Japan were $33.5 \mathrm{Tg}$ and $0.8 \mathrm{Tg}$, respectively: $\mathrm{SO}_{2}$ levels were more than 40 times higher 
in China than in Japan. Although it is considered that $\mathrm{SO}_{2}$ emissions in China have been decreasing since 2006, the $\mathrm{SO}_{2}$ concentration has been still high in China. It is reasonable that sulfate is found to be high when the trans-boundary air pollution is dominant under high $\mathrm{PM}_{2.5}$ concentration.

Nitrate was not found in $\mathrm{PM}_{1}$ measured using Q-AMS when $\mathrm{PM}_{2.5}$ concentrations were high. In 2008, $\mathrm{NO}_{x}$ emissions for China and Japan were $27.0 \mathrm{Tg}$ and $2.2 \mathrm{Tg}$, respectively: $\mathrm{NO}_{x}$ levels were about 13 times higher in China than in Japan. Although $\mathrm{NO}_{x}$ emissions are much higher in China compared to the $\mathrm{NO}_{x}$ emission in Japan, the nitrate is usually found in coarse particles after the long-range transport [12]. In contrast, sulfate remains in the fine particles. Therefore, sulfate is found to be the major chemical component of fine particulate matter $\left(\mathrm{PM}_{1}\right)$ when the trans-boundary air pollution is dominant.

Figure 9 shows the frequency of daily $\mathrm{PM}_{2.5}$ mass concentrations throughout 2012 for Fukuoka. There were a total of 20 days when $\mathrm{PM}_{2.5}$ mass concentrations exceeded environmental quality standard $\left(>35 \mu \mathrm{g} \cdot \mathrm{m}^{-3}\right)$, which are $5.5 \%$ per year and $11 \%$ in spring time (10 days between March-May). The air quality in Fukuoka, which is in the western part of Japan, is largely affected by trans-boundary, long-range transported air pollution from mainland China.

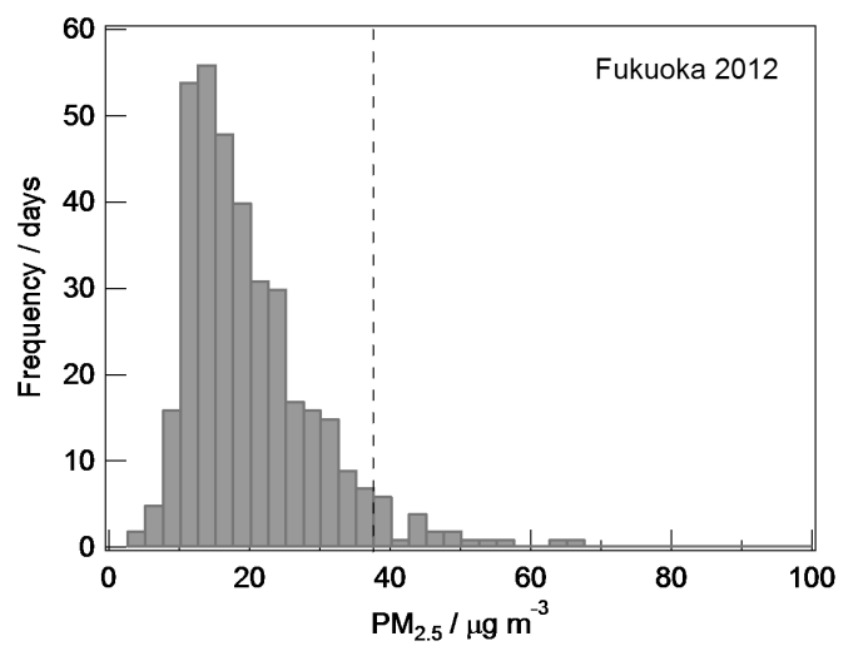

Figure 9. Frequency of daily $\mathrm{PM}_{2.5}$ mass concentrations throughout 2012 for Fukuoka City. Vertical dashed line is environmental quality standard in Japan for $24 \mathrm{~h}$ averaged $\mathrm{PM}_{2.5}$ mass concentrations.

\subsection{High $P M_{2.5}$ Event in Summer}

It was considered that trans-boundary air pollution was often observed in the winter-spring season. In 2012, high $\mathrm{PM}_{2.5}$ concentrations were observed during summer time. There were several days when the daily $\mathrm{PM}_{2.5}$ concentrations were over $35 \mu \mathrm{g} \cdot \mathrm{m}^{-3}$. Figure 10a shows hourly and daily averaged $\mathrm{PM}_{2.5}$ concentrations from 19 July to 2 August. The maximum daily $\mathrm{PM}_{2.5}$ concentration was $63.1 \mu \mathrm{g} \cdot \mathrm{m}^{-3}$ on $25 \mathrm{July}$. That day, a high $\mathrm{PM}_{2.5}$ concentration was also observed in Osaka [29]. The chemical and organic compositions are shown in Figure 11. The fraction of sulfate and factor 1 (LV-OOA) is about $50 \%$ and $60 \%$, respectively. There are several reasons for this high sulfate event. The first one is volcanic activities. There is an active volcano called Mt. Sakurajima in Kagoshima, which is about $300 \mathrm{~km}$ south to Fukuoka City $\left(31.34^{\circ} \mathrm{N}, 130.39^{\circ} \mathrm{E}\right)$. Explosive eruption have been occurring continuously since 1955. Mt. Sakurajima was active in summer 2012 and volcanic eruption occurred several times. During the high $\mathrm{PM}_{2.5}$ period shown in Figure 10b, high concentration peaks of $\mathrm{SO}_{2}$, measured at Fukuoka City Hall, were observed several times. The biggest eruption occurred at 19:15 on 24 July [30], and high sulfate and $\mathrm{SO}_{2}$ were observed on 25 July. Therefore, one of the reasons can be attributed to the volcanic activities. The second reason is photochemical reaction in the atmosphere. The fraction of factor 1 (LV-OOA) is about $60 \%$, which is not as high as that on Fukue Island during winter-spring season and similar to the average values of urban OOA [31]. Therefore, the 
aged and oxygenated organic compounds in urban area certainly contributed the factor 1 (LV-OOA). The third one is trans-boundary air pollution. The CFORS simulation for 25 July shows that the high sulfate area covers the northern Kyushu region shown in Figure 12. The high sulfate area originally covered in the mainland China on 20 July, and the area moved to the northern part of China and the Korean peninsula. Then, a part of high sulfate area moved down to the southern area and covered some part of Japan. A simulation called SPRINTARS also shows that the high sulfate region averaged in July 2012 covered the northern part of Kyushu and the west Japanese region facing the Japan Sea [29]. This high sulfate region moved from China to Japan during this high $\mathrm{PM}_{2.5}$ concentration period (from 20 to 28 July). Although we do not know if summer levels in 2012 were unique, this high $\mathrm{PM}_{2.5}$ concentration event shows that trans-boundary air pollution occurs not only in winter-spring but also in summer and plays a significant role in air quality for Fukuoka City.
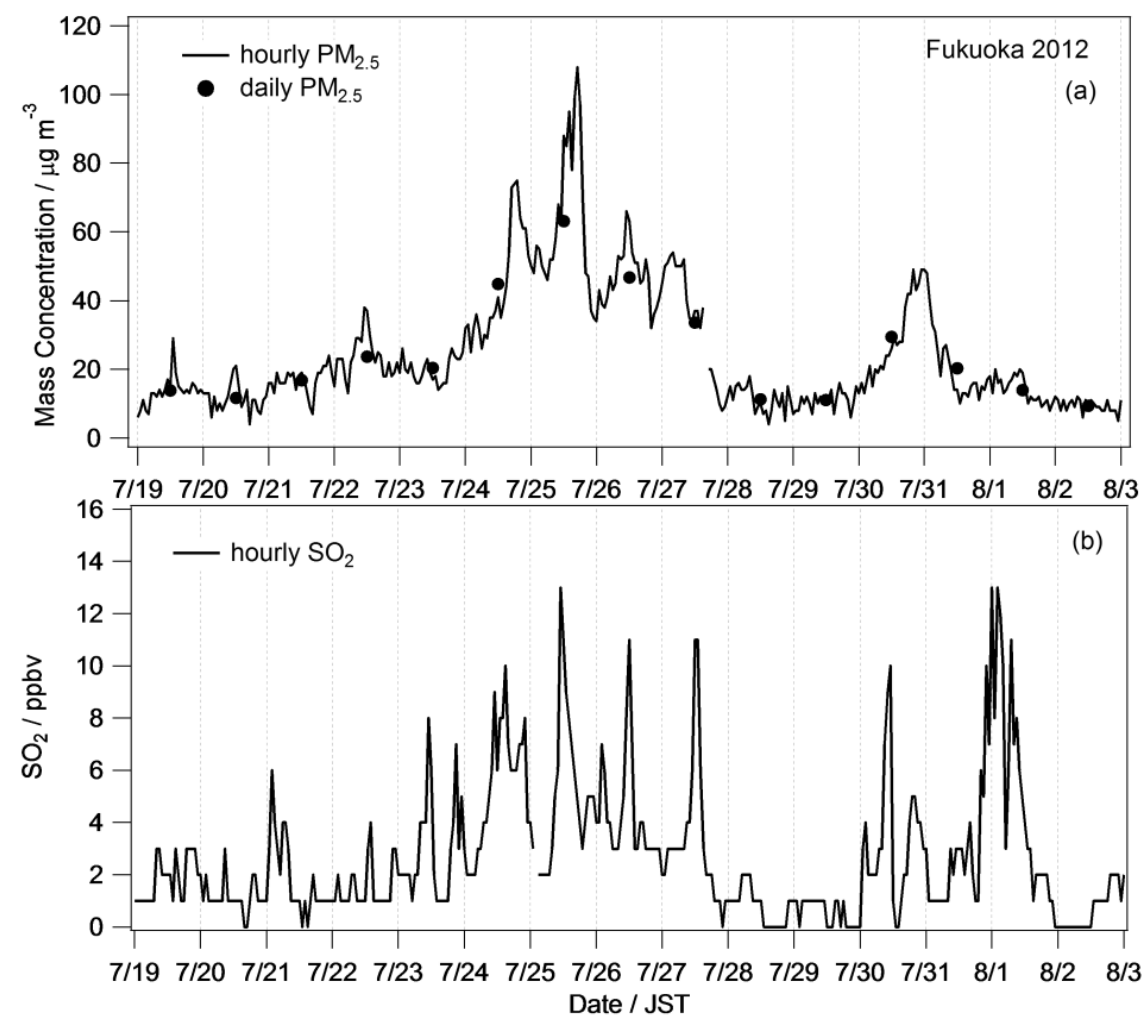

Figure 10. Variations of mass concentrations of $\mathrm{PM}_{2.5}$ and of mixing ratio of $\mathrm{SO}_{2}$ from 19 July to 2 August in Fukuoka City. (a) wolid line is hourly averaged $\mathrm{PM}_{2.5}$, closed circles are daily averaged $\mathrm{PM}_{2.5} ;(\mathbf{b})$ hourly averaged $\mathrm{SO}_{2}$.
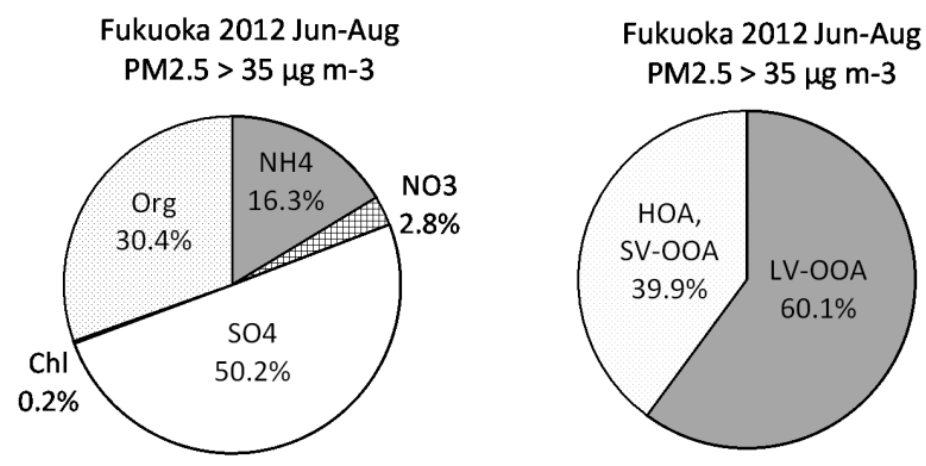

Figure 11. Breakdown of chemical composition measured using Q-AMS and each factor of PMF analysis from June to August of 2012 for Fukuoka City. 


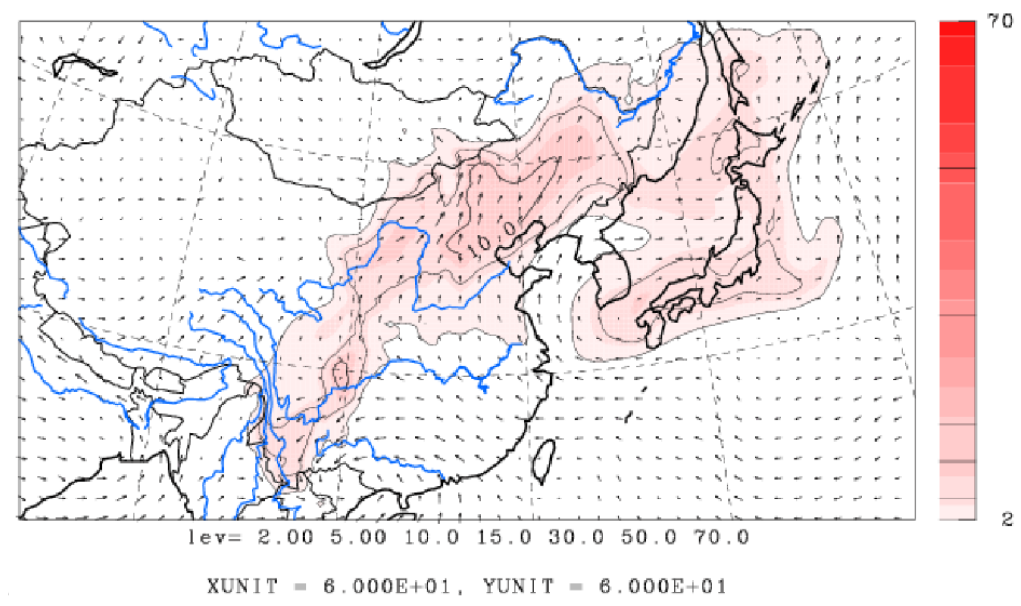

Figure 12. CFORS simulations around East Asia on 25 July.

\section{Conclusions}

This study observed PM mass concentrations and chemical compositions in Fukuoka and Fukue Island in the northern part of Kyushu, Japan in 2012. Based on the chemical analysis, air quality in Fukuoka City was influenced by trans-boundary air pollution when the $\mathrm{PM}_{2.5}$ concentrations were high. It was found that sulfate and LV-OOA were dominant under high $\mathrm{PM}_{2.5}$ concentrations $\left(>35 \mu \mathrm{g} \cdot \mathrm{m}^{-3}\right)$, and the air mass was transported from China according to backward trajectories and CFORS simulations. It is considered that local emissions influence the air quality in Fukuoka City when $\mathrm{PM}_{2.5}$ concentrations are low. The fractions of nitrate and organics of non-LV-OOA were large under low $\mathrm{PM}_{2.5}$ concentration $\left(<10 \mu \mathrm{g} \cdot \mathrm{m}^{-3}\right)$, and the air mass passed around the Pacific Ocean and Japanese side.

There were a total of 20 days when the $\mathrm{PM}_{2.5}$ mass concentrations exceeded environmental quality standards $\left(>35 \mu \mathrm{g} \cdot \mathrm{m}^{-3}\right)$ in Fukuoka. High $\mathrm{PM}_{2.5}$ concentrations were observed in summer 2012. Three reasons are considered, which are volcanic activities, photochemical reaction and trans-boundary air pollution. Although previous studies have shown that trans-boundary air pollution prevails in the winter-spring season, it occurs not only in winter-spring but also in summer and has a significant impact on the air quality of Fukuoka.

Acknowledgments: This work was supported by The Ministry of Education, Culture, Sports, Science and Technology, Grants-in-Aid for Scientific Research (Grant-in-Aid for Scientific Research on Innovative Areas No. 4003), Japan Society for the Promotion of Science, Grants-in-Aid for Scientific Research (Grant No. 24310024), and the Ministry of Environment, Environment Research and Technology Development Fund, Japan (Grant No. 5-1452, 2-1403, S-12). We thank Satoshi Irei for his support of our observation.

Author Contributions: Ayako Yoshino and Akinori Takami conceived and designed the experiments and performed the AMS and ACSM experiments; Naoki Kaneyasu performed the TEOM experiments; Atsushi Shimizu performed the CFORS simulations; Ayako Yoshino analyzed the data; Kei Sato, Shiro Hatakeyama, Keiichiro Hara, and Masahiko Hayashi contributed experiments and analysis tools; Ayako Yoshino and Akinori Takami wrote the paper.

Conflicts of Interest: The authors declare no conflict of interest.

\section{Abbreviations}

The following abbreviations are used in this manuscript:

PM

Particulate matter

Q-AMS

Quadrupole-type aerosol mass spectrometer 


$\begin{array}{ll}\text { Q-ACSM } & \text { Quadrupole-type aerosol chemical speciation monitor } \\ \text { TEOM } & \text { Tapered element oscillating microbalance } \\ \text { PMF } & \text { Positive matrix factorization } \\ \text { CFORS } & \text { Chemical weather forecasting system } \\ \text { OA } & \text { Organic aerosol } \\ \text { LV-OOA } & \text { Low-volatile oxygenated OA } \\ \text { SV-OOA } & \text { Semi- volatile oxygenated OA } \\ \text { HOA } & \text { Hydrocarbon-like OA }\end{array}$

\section{References}

1. Kurokawa, J.; Ohara, T.; Morikawa, T.; Hanayama, S.; Janssens-Maenhout, G.; Fukui, T.; Kawashima, K.; Akimoto, H. Emissions of air pollutants and greenhouse gases over Asian regions during 2000-2008: Regional Emission Inventory in ASia (REAS) Version 2. Atmos. Chem. Phys. 2013, 13, 11019-11058. [CrossRef]

2. Lu, Z.; Streets, D.G.; Zhang, Q.; Wang, S.; Carmichael, G.R.; Cheng, Y.F.; Wei, C.; Chin, M.; Diehl, T.; Tan, Q. Sulfur dioxide emissions in China and sulfur trends in East Asia since 2000. Atmos. Chem. Phys. 2010, 10, 6311-6331. [CrossRef]

3. Takami, A.; Miyoshi, T.; Shimono, A.; Hatakeyama, S. Chemical composition of fine aerosol measured by AMS at Fukue Island, Japan during APEX Period. Atmos. Environ. 2005, 39, 4913-4924. [CrossRef]

4. Takami, A.; Miyoshi, T.; Shimono, A.; Kaneyasu, N.; Kato, S.; Kajii, Y.; Hatakeyama, S. Transport of anthropogenic aerosols from Asia and subsequent chemical transformation. J. Geophys. Res. 2007, 112, D22S31. [CrossRef]

5. Kanaya, Y.; Taketani, F.; Irie, H.; Komazaki, Y.; Takashima, H.; Uno, I. PM 2.5 mass concentrations observed at Fukue island, Kyushu, Japan: Exceeding the atmospheric environmental standard. J. Jpn. Soc. Atmos. Environ. 2010, 45, 289-292. (In Japanese)

6. Kaneyasu, N.; Takami, A.; Sato, K.; Hatakeyama, S.; Hayashi, M.; Hara, K.; Lim-Serok, C.; Joon-Young, A. Long-range transport of $\mathrm{PM}_{2.5}$ in northern Kyushu area in spring. J. Jpn. Soc. Atmos. Environ. 2010, 45, 227-234. (In Japanese)

7. Kaneyasu, N.; Takami, A.; Sato, K.; Hatakeyama, S.; Hayashi, M.; Hara, T.; Kawamoto, K.; Yamamoto, S. Year-round behavior of $\mathrm{PM}_{2.5}$ in a remote island and urban sites in northern Kyushu area, Japan. J. Jpn. Soc. Atmos. Environ. 2011, 46, 111-118. (In Japanese)

8. Takami, A.; Mayama, N.; Sakamoto, T.; Ohishi, K.; Irei, S.; Yoshino, A.; Hatakeyama, S.; Murano, K.; Sadanaga, Y.; Bandow, H.; et al. Structural analysis of aerosol particles by microscopic observation using a time-of-flight secondary ion mass spectrometer. J. Geophys. Res. 2013, 118, 6726-6737. [CrossRef]

9. Takami, A.; Miyoshi, T.; Irei, S.; Yoshino, A.; Sato, K.; Shimizu, A.; Hayashi, M.; Hara, K.; Kaneyasu, N.; Hatakeyama, S. Analysis of organic aerosol in Fukuoka, Japan using a PMF method. Aerosol Air Qual. Res. 2016, 16, 314-322. [CrossRef]

10. Murano, K.; Mukai, H.; Hatakeyama, S.; Jang, E.S.; Uno, I. Trans-boundary air pollution over remote islands in Japan: Observed data and estimates from a numerical model. Atmos. Environ. 2000, 34, 5139-5149. [CrossRef]

11. Shimohara, T.; Oishi, O.; Utsunomiya, A.; Mukai, H.; Hatakeyama, S.; Jang, E.-S.; Uno, I.; Murano, K. Characterization of atmospheric air pollutants at two sites in northern Kyushu, Japan-Chemical form, and chemical reaction. Atmos. Environ. 2001, 35, 667-681. [CrossRef]

12. Takiguchi, Y.; Takami, A.; Sadanaga, Y.; Lun, A.; Shimizu, A.; Matsui, I.; Sugimoto, N.; Wang, W.; Bandow, H.; Hatakeyama, S. Transport and transformation of total reactive nitrogen over the East China Sea. J. Geophys. Res. 2008, 113, D10306. [CrossRef]

13. Jayne, J.T.; Leard, D.C.; Zhang, X.; Davidovits, P.; Smith, K.A.; Kolb, C.E.; Worsnop, D.R. Development of an Aerosol mass spectrometer for size and composition analysis of submicron particles. Aerosol Sci. Technol. 2000, 33, 49-70. [CrossRef]

14. Allan, J.D.; Jimenez, J.L.; Coe, H.; Bower, K.N.; Williams, P.I.; Worsnop, D.R. Quantitative sampling using an Aerodyne aerosol mass spectrometer: Part 1. techniques of data interpretation and error analysis. J. Geophys. Res. 2003, 108. [CrossRef] 
15. Allan, J.D.; Alfarra, M.R.; Bower, K.N.; Williams, P.I.; Gallagher, M.W.; Jimenez, J.L.; McDonald, A.G.; Nemitz, E.; Canagaratna, M.R.; Jayne, J.T.; et al. Quantitative sampling using an Aerodyne aerosol mass spectrometer: Part 2. Measurements of fine particulate chemical composition in two U.K. cities. J. Geophys. Res. 2003, 108. [CrossRef]

16. Jimenez, J.L.; Jayne, J.T.; Shi, Q.; Kolb, C.E.; Worsnop, D.R.; Yourshaw, I.; Seinfeld, J.H.; Flagan, R.C.; Zhang, X.; Smith, K.A.; et al. Ambient aerosol sampling using the Aerodyne aerosol mass spectrometer. J. Geophys. Res. 2003, 108. [CrossRef]

17. Canagaratna, M.R.; Jayne, J.T.; Jimenez, J.L.; Allan, J.D.; Alfarra, M.R.; Zhang, Q.; Onasch, T.B.; Drewnick, F.; Coe, H.; et al. Chemical and microphysical characterization of ambient aerosols with the Aerodyne aerosol mass spectrometer. Mass Spect. Rev. 2007, 26, 185-222. [CrossRef] [PubMed]

18. Paatero, P.; Tapper, U. Positive matrix factorization: A non negative factor model with ; Weimer, S. Optimal utilization of error estimates of data values. Environmetrics 1994, 5, 111-126. [CrossRef]

19. Paatero, P. Least squares formulation of robust non-negative factor analysis. Chem. Intell. Lab. Syst. 1997, 37, 23-35. [CrossRef]

20. Ulbrich, I.M.; Canagaratna, M.R.; Zhang, Q.; Worsnop, D.R.; Jimenez, J.L. Interpretation of organic components from positive matrix factorization of aerosol mass spectrometric data. Atmos. Chem. Phys. 2009, 9, 2891-2918. [CrossRef]

21. Draxler, R.R.; Rolph, G.D. HYSPLIT (HYbrid Single-Particle Lagrangian Integrated Trajectory) Model. Available online: http:/ / ready.arl.noaa.gov/HYSPLIT.php (accessed on 1 February 2016).

22. Rolph, G.D. Real-time Environmental Applications and Display sYstem (READY). Available online: http:/ / ready.arl.noaa.gov (accessed on 1 February 2016).

23. Uno, I.; Carmichael, G.R.; Streets, D.G.; Tang, Y.; Yienger, J.J.; Satake, S.; Wang, Z.; Woo, J.H.; Guttikunda, S.; Uematsu, M.; et al. Regional chemical weather forecasting system CFORS: Model descriptions and analysis of surface observations at Japanese island stations during the ACE-Asia experiment. J. Geophys. Res. 2003, 108, 8668. [CrossRef]

24. CFORS (Chemical Weather FORecasting System). Available online: http://www-cfors. nies.go.jp/ cfors / (accessed on 1 February 2016).

25. Jimenez, J.L.; Canagaratna, M.R.; Donahue, N.M.; Prevot, A.S.H.; Zhang, Q.; Kroll, J.H.; DeCarlo, P.F.; Allan, J.D.; Coe, H.; Ng, N.L.; et al. Evolution of organic aerosols in the atmosphere. Science 2009, 326, 1525-1529. [CrossRef] [PubMed]

26. Alfarra, M.R.; Coe, H.; Allan, J.D.; Bower, K.N.; Boudries, H.; Canagaratna, M.R.; Jimenez, J.L.; Jayne, J.T.; Garforth, A.A.; Li, S.-M.; et al. Characterization of urban and rural organic particulate in the Lower Fraser Vally using two Aerodyne Aerosol Mass Spectrometers. Atmos. Environ. 2004, 38, 5745-5758. [CrossRef]

27. Zhang, Q.; Canagaratna, M.R.; Jayne, J.T.; Worsnop, D.R.; Jimenez, J.L. Time-and size-resolved chemical composition of submicron particles in Pittsburgh: Implications for organic aerosol sources and processes. J Geophys. Res. 2005, 110, D07S09. [CrossRef]

28. Ohara, T.; Akimoto, H.; Kurokawa, J.; Horii, N.; Yamaji, K.; Yan, X.; Hayasaka, T. An Asian emission inventory of anthropogenic emission sources for the period 1980-2020. Atmos. Chem. Phys. 2007, 7, 4419-4444. [CrossRef]

29. Takami, A.; Irei, S.; Kimoto, T.; Takemura, T.; Hayashi, M.; Hara, K.; Miyoshi, T.; Ueda, K.; Sato, K.; Kaneyasu, N.; et al. An analysis of high sulfate ion events in Fukuoka and Osaka city in summer 2012. Earozoru. Kenkyu. 2013, 28, 281-286. (In Japanese)

30. Watanabe, K.; Yamazaki, N.; Mizouchi, R.; Iwamoto, Y.; Matsuki, A.; Sadanaga, Y.; Bandow, H.; Iwasaka, Y. High concentrations of sulfur dioxide and sulfate particles observed in Suzu city, the Noto peninsula in late July 2012: On the influence of the smoke of Sakurajima. Tenki 2015, 62, 201-208. (In Japanese)

31. Zhang, Q.; Jimenez, J.L.; Canagaratna, M.R.; Allan, J.D.; Coe, H.; Ulbrich, I.; Alfarra, M.R.; Takami, A.; Middlebrook, A.M.; Sun, Y.L.; et al. Ubiquity and dominance of oxygenated species in organic aerosols in anthropogenically-influenced Northern Hemisphere midlatitudes. Geophys. Res. Lett. 2007, 34, L13801. [CrossRef]

(C) 2016 by the authors; licensee MDPI, Basel, Switzerland. This article is an open access article distributed under the terms and conditions of the Creative Commons by Attribution (CC-BY) license (http://creativecommons.org/licenses/by/4.0/). 